\title{
Assessment of the Biodegradability and Ecotoxicty of a Nonylphenol Ethoxylate Surfactant in Littoral Waters
}

\author{
J. M. Quiroga, M. C. Garrido, L. I. Romero, D. Sales Márquez, and J. A. Perales
}

\begin{abstract}
Biodegradability and ecotoxicity of the nonionic surfactant Tergitol $^{\circledR}$ NP9 were studied in sea water samples collected from the Gulf of Cadiz (Spain). In order to study the biodegradation process we followed the guideline 835.3160 "Biodegradability in sea water" proposed by the United States Environmental Protection Agency (USEPA). Growth inhibition tests on different marine microalgae species and mortality tests on a marine crustacean (Artemia franciscana) were carried out. Biodegradation process was modelled according to a first order kinetic model. Lag time and half-life were 0.75 and 4.95 days, respectively, which indicates that Tergitol $^{\circledR}$ NP9 can be mineralised in sea water. Depending on the microalgae, 96-h $\mathrm{EC}_{50}$ values ranged from 3.45 to $25.82 \mathrm{mg} \mathrm{L}^{-1}$. 48-h and $72-\mathrm{h}$ $\mathrm{LC}_{50}$ to $A$. franciscana were 41.2 and $30.34 \mathrm{mg} \mathrm{L}^{-1}$, respectively. Marine crustacean was more resistant than the microalgae. Surfactant tolerance on microalgae followed this order: $T$. chuii $>$ D. salina $>$ N. gaditana $>$ I. galbana $\approx$ C. gracilis.
\end{abstract}

Index Terms-NPEO, surfactant, biodegradation, toxicity, sea water, microalga, $A$ franciscana.

\section{INTRODUCTION}

Nonylphenol ethoxylates (NPEOs) are an important group of nonionic surfactants with a wide range of applications such as detergents, emulsifiers, dispersants, antifoamers and pesticides adjuvants. Alkylphenol ethoxylates have an annual global production of around 700,000 tons. These compounds have been found in domestic sewage and industrial effluents occurring occasionally relatively high levels of nonylphenol ethoxylates in natural water bodies [1].

Several aerobic degradation pathways for NPEOs have been suggested by different authors. In general, the biodegradation process starts with the shortening of the ethoxylate chains by mean of hydrolysis reactions, leading to short-chain nonylphenol ethoxylates (NP1EO and NP2EO, mainly) [2]. Complete deethoxylation has been observed only under anaerobic conditions. On the other hand, the formation of nonylphenol polyethoxycarboxylates (mainly NP1EC and NP2EC) occurs via oxidation of the ethoxylate chain [3]. In addition, oxidation is also attributed to the degradation of the alkyl chain with the formation of octylphenol polyethoxylates.

Nonylphenol ethoxylates have been identified as an

Manuscript received July 11, 2018; revised April 3, 2019.

J. M. Quiroga is with the Area of Environmental Technologies, CACYTMAR, Campus of Puerto Real. Poligono Rio San Pedro s/n. 11510 Puerto Real, Cadiz, Spain (e-mail: josemaria.quiroga@uca.es).

M. C. Garrido, L. I. Romero, D. Sales Márquez, and J. A. Perales are with Area of Environmental Technologies, CACYTMAR, Campus of Puerto Real, Poligono Rio San Pedro s/n. 11510 Puerto Real, Cadiz, Spain. important toxic group to marine and freshwater organisms [4]. It is assumed that the decreasing EO chain length increases the toxicity of the compound [5]. Moreover, some metabolites show higher toxicity than the precursor [6] and even may disrupt the hormonal cycles of organisms [7]. One of the most widely studied metabolites is the nonylphenol (4-NP). It has been demonstrated to exhibit estrogenic effects, being responsible for adverse effects on reproductive organs and developmental processes [8]. For these reasons and in order to phase-out its use, it has been included in the list of priority substances under the Water Framework Directive (2000/60/CE)

This study was performed to evaluate the biodegradability and ecotoxicity of the nonylphenol ethoxylate Tergitol ${ }^{\circledR}$ NP9 in sea water from a littoral area of Gulf of Cadiz (Spain). This involved parallel testing of biodegradation and standardised toxicity on marine organisms. Based on the procedure proposed by [9] different kinetic models were applied in order to study the biodegradation rate in sea water. For the study of the toxicity to microalgae and microcrustacea, growth inhibition and mortality tests were carried out, respectively. The knowledge of these environmental properties is fundamental for the assessment of the environmental risks generated by the presence of these compounds in marine environments.

\section{MATERIALS AND MethodS}

\section{A. Chemicals}

Sodium benzoate, chemicals used for the nutrients solutions and the nonionic surfactant Tergitol ${ }^{\circledR}$ NP9 (CAS number 127087-87-0) were supplied by Fluka Chemie A.G. (Barcelona, Spain). The surfactant consists a mix of oligomers with an average number of 9.3 ethoxy units and a reported purity of $>99.7 \%$ of active matter. Surfactant structure is given in Fig. 1.

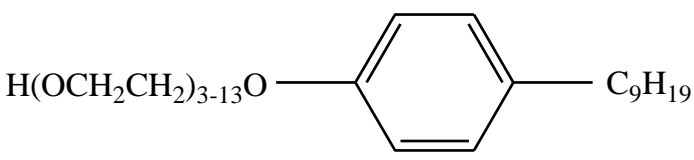

Fig. 1. Chemical structure of the nonionic surfactant nonylphenol ethoxylate (Tergitol $^{\circledR}$ NP9) tested.

\section{B. Test Medium}

Pristine sea water samples for the biodegradation and toxicity tests were collected from the littoral area of Sancti Petri (Gulf of Cadiz, southwest of Iberian Peninsula). Main physico-chemical and biological characteristics of the sea water used are summarized in Table I. 


\section{Biodegradation Tests}

Ultimate biodegradation of the surfactant was studied following the guideline OPPTS (Office of Prevention, Pesticides and Toxic Substances) 835.3160 "Biodegradability in sea water", proposed by the United States Environmental Protection Agency. The shake flask method was employed in all the biodegradation tests. A positive result in the test ( $>70 \%$ DOC removal before 60 days) might indicate that there is a potential for the biodegradation in the marine environment. However, a negative result does not preclude such potential but indicates that further study is necessary, for example using as low a concentration of the test substance as possible.

TABLE I: ANALYSIS OF SEA WATER USED IN THE BIODEGRADATION AND TOXICITY TESTS. DATA ARE PRESENTED AS MEAN \pm STANDARD DEVIATION

\begin{tabular}{|c|c|c|}
\hline \multicolumn{3}{|c|}{$(N=3)$} \\
\hline Parameter & Units & Value \\
\hline Dissolved Oxygen & $\%$ saturation & $61.4 \pm 1.22$ \\
\hline Temperature & ${ }^{\circ} \mathrm{C}$ & $19.5 \pm 0.3$ \\
\hline Conductivity & $\mathrm{mS} \mathrm{cm}{ }^{-1}$ & $35.6 \pm 0.25$ \\
\hline $\mathrm{pH}$ & - & $8.10 \pm 0.04$ \\
\hline Salinity & - & $36.8 \pm 0.42$ \\
\hline Total carbon & $\mathrm{mg} \mathrm{L}^{-1} \mathrm{C}$ & $27.38 \pm 0.54$ \\
\hline Inorganic carbon & $\mathrm{mg} \mathrm{L}^{-1} \mathrm{C}$ & $26.21 \pm 0.52$ \\
\hline Organic carbon & $\mathrm{mg} \mathrm{L}^{-1} \mathrm{C}$ & $1.17 \pm 0.02$ \\
\hline Nitrites & $\mathrm{mg} \mathrm{L}^{-1} \mathrm{NO}_{2}^{-}$ & $<0.015$ \\
\hline Nitrates & $\mathrm{mg} \mathrm{L}^{-1} \mathrm{NO}_{3}^{-}$ & $<0.020$ \\
\hline Ammonia & $\mathrm{mg} \mathrm{L}^{-1} \mathrm{NH}_{4}^{+}$ & $<0.007$ \\
\hline Phosphate & $\mathrm{mg} \mathrm{L}^{-1} \mathrm{PO}_{4}^{3-}$ & $<0.015$ \\
\hline Silicates & $\mathrm{mg} \mathrm{L}^{-1} \mathrm{Si}$ & $0.018 \pm 0.002$ \\
\hline Total hardness & $\mathrm{mg} \mathrm{L}^{-1} \mathrm{Ca}^{2+}$ & $320 \pm 20.2$ \\
\hline Chlorophyll a & $\mathrm{mg} \mathrm{m}^{-3} \mathrm{Cl} \mathrm{a}$ & $0.85 \pm 0.10$ \\
\hline Faecal streptococcus & $\mathrm{CFU} 100 \mathrm{~mL}^{-1}$ & $1 \pm 1.49$ \\
\hline Faecal coliforms & CFU $100 \mathrm{~mL}^{-1}$ & $\mathrm{ND}^{\mathrm{a}}$ \\
\hline Enterococcus & CFU $100 \mathrm{~mL}^{-1}$ & $\mathrm{ND}^{\mathrm{a}}$ \\
\hline
\end{tabular}

Sea water samples were taken with a Ruttner oceanographic bottle, filtered through $1 \mu \mathrm{m}$ glass fiber filters and enriched with different nutrient solutions. After a 24-h acclimation in darkness at $18 \pm 1^{\circ} \mathrm{C}$ a volume of $1.5 \mathrm{~L}$ of pre-treated sea water was added to $2.5 \mathrm{~L}$ amber borosilicate bottles. Finally, a volume of surfactant solution was added in order to obtain a final concentration of $15 \mathrm{mg} \mathrm{DOC} / \mathrm{L}$, approximately. Biodegradation tests were carried out in darkness at $18 \pm 1^{\circ} \mathrm{C}$.

Biodegradation experiment was constituted by a) a control test, composed only by pre-treated sea water, b) a reference test, containing pre-treated sea water and sodium benzoate concentration of $15 \mathrm{mg} \mathrm{DOC} \mathrm{L}^{-1}, \mathrm{c}$ ) an abiotic test, formed by pre-treated sea water, a surfactant concentration of $15 \mathrm{mg}$ DOC L ${ }^{-1}$, approximately, and $100 \mathrm{mg} \mathrm{L}^{-1}$ of mercury chloride, and d) a triplicate, containing pre-treated sea water and an initial surfactant concentration of around $15 \mathrm{mg}$ DOC $\mathrm{L}^{-1}$. The reference test was used to check the microbial activity of the sea water samples whereas the abiotic test was used to ensure that no other removal processes (photo-degradation, adsorption, precipitation, etc) were occurring.

Control parameters (temperature, $\mathrm{pH}$ and oxygen concentration) were periodically measured to ensure the optimal conditions of biodegradation. DOC was measured in accordance with the standard method of infrared combustion 5310B [10] using a carbon analyzer Shimazdu TOC-5050. Samples were filtered through a $0.22 \mu \mathrm{m}$ polyvinylidene fluoride filter (Millipore S.A.) prior to analysis of DOC.

\section{Algal Toxicity Tests}

Growth inhibition tests using five marine microalgae species (Nannochloropsis gaditana, Isochrysis galbana, Chaetoceros gracilis, Dunaliella salina and Tetraselmis chuii) were carried out. The procedure was based on standard methods proposed by USEPA [11] APHA-AWWA-WPCF [10], Organisation for Economic Co-operation and Development [12] and several authors. Microalgae were purchased by Andalusian Institute of Marine Sciences, ICMAN-CSIC (Cadiz, Spain). Microalgae inocula were cultivated under aseptic conditions at $20 \pm 1{ }^{\circ} \mathrm{C}$ and 24-h light in $500 \mathrm{~mL}$ Erlenmeyer flasks containing $100 \mathrm{~mL}$ synthetic sea water [10] and a supply of nutrients and vitamins according to the $f / 2$ medium modified with double nitrate and phosphate concentrations and silicate $\left(250 \mu \mathrm{g} / \mathrm{L} \mathrm{SiO}{ }_{2}\right)$. Biomass concentrations were estimated by the optical density of the culture at $690 \mathrm{~nm}$ (OD $690 \mathrm{~nm})$. Initial absorbance between 0.200 and 0.300 was used in order to ensure exponential growth.

Inhibition growth tests were conducted using $10 \mathrm{~mL}$ glass vials containing $2 \mathrm{~mL}$ of inoculum and $2 \mathrm{~mL}$ of Tergitol ${ }^{\circledR}$ NP9 enriched with modified f/2 medium. Cultures were kept at $20 \pm 1{ }^{\circ} \mathrm{C}$, under 11000 Lux light intensity and photoperiod of 24-h. After 24, 48, 72 and 96 hours biomass concentration was determined. Ten different surfactant concentrations and a control were tested in triplicate for every microalga species.

\section{E. Crustacea Toxicity Tests}

Marine microcrustacean Artemia franciscana was exposed to increasing concentrations of Tergitol ${ }^{\circledR}$ NP9. Mortality tests based on standard methods proposed by USEPA [11], APHA-AWWA-WPCF [10], Organisation for Economic Co-operation and Development [12] and American Society for Testing and Materials [13] were carried out. Cysts were purchased by Andalusian Institute of Marine Sciences, ICMAN-CSIC (Cadiz, Spain).

A. franciscana cysts were hatched in $100 \mathrm{ml}$ of synthetic sea water [10]. The incubation was carried out under 11000 Lux light intensity, at $20 \pm 1{ }^{\circ} \mathrm{C}$ and a slight aeration. Under these conditions, the time required for the cysts to hatch was approximately 24 hours.

The hatched nauplii were separated from shells and remaining cysts using a Pasteur pipette and transferred to fresh sea water. Ten organisms, contained in a lower volume to $50 \mu \mathrm{L}$, were pipetted into a glass Petri dish $(55 \mathrm{~mm}$ diameter). Subsequently, $8 \mathrm{~mL}$ of surfactant solution was 
added. Ten different surfactant concentrations and a control were tested in quintuplicate. The test was carried out in darkness at $20 \pm 1{ }^{\circ} \mathrm{C}$. After 48 and 72 hours, alive and dead individuals were recounted. One or two preliminary studies were conducted in order to know the dose range where mortality around $50 \%$ is achieved.

\section{F. Statistical Analysis}

Kinetic modelling of the surfactant degradation process was performed by non-linear estimation using the quasi-Newton method (Statistica 4.0, Statsoft, Inc., 1993). In order to assess the goodness-of-fit of the model a Chi square $\left(\chi^{2}\right)$ distribution was used. Thus, $\mathrm{Q}$, the probability that $\chi^{2}$ should exceed a particular value by chance, gives a quantitative measure or the goodness-of-fit of the model. Low $Q$ values indicate that the apparent discrepancies are unlikely to be chance fluctuations, so the model can be rejected. Likewise, $Q$ values too close to the unity indicate an excellent fit of the model; literally too good to be true. Often, its cause is an overestimation of the measurement errors. In general, a good value of $\chi^{2}$ for a moderately good fit is $\chi^{2} \cong v$, where $v$ is the number of degrees freedom $(v=N-M, N$ is the number of data points and $\mathrm{M}$ the number of parameters to be fitted [14]. Once the best-fit model was selected, the values of the lag time $\left(\mathrm{t}_{\mathrm{L}}\right)$, the half-life $\left(\mathrm{t}_{1 / 2}\right)$ and the time starting from the end of the lag phase to reach the $50 \%$ of biodegradation $\left(\mathrm{t}_{50}\right)$ were calculated according to the methodology proposed by Perales et al. [9].

Microalgae growth rates were analysed statistically [15] by linear interpolation to determinate $96-\mathrm{h} \mathrm{EC}_{50}$ values. For the crustacean, 48-h and 72-h $\mathrm{LC}_{50}$ values were calculated by Probit analysis in accordance with the procedure proposed by USEPA [10]. No-observed-effect concentration (NOEC) and lowest-observed-effect concentration (LOEC) were calculated by Dunnett's or Steel's test depending on the results obtained for normality and homogeneity of variances using Shapiro-Wilk's and Bartlett's tests, respectively [10]. Statistical analyses were conducted using ICp and ToxStat softwares.

\section{RESULTS}

\section{A. Ultimate Biodegradation}

Temperature, $\mathrm{pH}$ and oxygen measurements (mean \pm standard deviation, SD) during the biodegradation experiment were within $18.1 \pm 0.12{ }^{\circ} \mathrm{C}, 8.17 \pm 0.001$ and $77.17 \pm 0.49 \%$ of saturation, respectively. The mineralisation percentage reached by the reference substance (sodium benzoate) was $>50 \%$ after 5 days and $>85 \%$ by 9 day, indicating that the microbial activity of the sea water samples was appropriate. In the abiotic test the mineralisation was $1.67 \pm 2.78 \%$, showing that the contribution of abiotic processes to the surfactant removal can be discounted in the biodegradation tests conducted.

Surfactant DOC removal over the biodegradation experiment is given in Fig. 2.

No lag phase was observed in the biodegradation process. After 3 and 7 days, DOC removal percentages were higher than $30 \%$ and $60 \%$, respectively. By day 24 DOC removal reached higher percentages than $95 \%$, showing an extensive biodegradability under the tested conditions. In order to study the degradation kinetic process several kinetic models proposed by Simkins and Alexander [16] and Quiroga et al. [17] were applied. The most appropriate kinetic model was selected according to the correlation with the experimental data $\left(r^{2}\right)$, biological meaning of parameters and analysis of $\chi^{2}$ Estimated kinetic and statistical parameters resulting from the modelling of the experimental data are given in Table II.

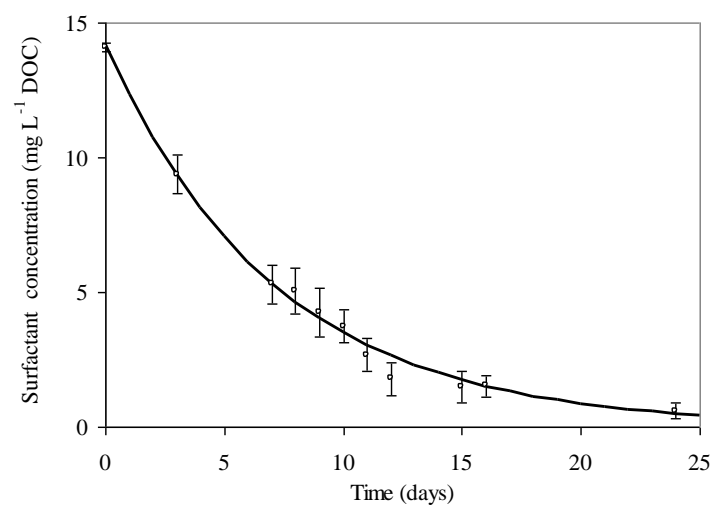

Fig. 2. Evolution of Tergitol ${ }^{\circledR} \mathrm{NP} 9$ concentration $\left(\mathrm{mg} \mathrm{DOC} \mathrm{L}^{-1}\right)$ in the biodegradation tests. Experimental data are expressed as mean $\pm \mathrm{SD}(\mathrm{n}=3)$. Solid line represents the fitted curve according to the first order model

In spite of the fact strong correlations $\left(r^{2}>0.97\right)$ were obtained for all the models, only the parameters estimated from the first order model remained within the biologically meaningful range. In addition, the analysis of $\chi^{2}$ showed $\mathrm{Q}$ value closer to unity for the first order model, indicating that the apparent discrepancies between the data set and the models were most probably chance fluctuations. Fig. 2 represents the experimental data fitted by the first order model (solid line).

TABLE II: VALUES OF THE KINETIC PARAMETERS AND THE ASSOCIATED STATISTICAL PARAMETERS OBTAINED FOR THE NONIONIC SURFACTANT TERGITOL ${ }^{\circledR}$ NP9

\begin{tabular}{|c|c|c|c|c|c|c|}
\hline \multirow[b]{2}{*}{ Model } & \multirow{2}{*}{\multicolumn{2}{|c|}{ Kinetic parameter ${ }^{a}$}} & \multicolumn{4}{|c|}{ Statistical parameter } \\
\hline & & & $\mathbf{r}^{2}$ & $\chi^{2}$ & $v$ & $\mathbf{Q}$ \\
\hline \multirow{2}{*}{$\begin{array}{l}\text { First } \\
\text { order }^{b}\end{array}$} & $\mathrm{~S}_{0}\left(\mathrm{mg} \mathrm{DOC} \mathrm{L}^{-1}\right)$ & $\begin{array}{l}14.21 \pm \\
1.74\end{array}$ & & & & \\
\hline & $\mathrm{K}_{1}\left(\mathrm{~d}^{-1}\right)$ & $\begin{array}{l}0.141 \pm \\
0.025\end{array}$ & 0.97 & 3.2 & 9 & 0.69 \\
\hline \multirow{3}{*}{ Logistic $^{b}$} & $\left.\mathrm{~S}_{0}(\mathrm{mg} \mathrm{DOC} \mathrm{L})^{-1}\right)$ & $\begin{array}{l}14.05 \pm \\
1.87\end{array}$ & \multirow{3}{*}{0.98} & \multirow{3}{*}{4.4} & \multirow{3}{*}{8} & \\
\hline & $\mathrm{B}_{0}\left(\mathrm{mg} \mathrm{DOC} \mathrm{L}^{-1}\right)$ & $\begin{array}{l}38.18 \pm \\
41.65\end{array}$ & & & & \multirow{2}{*}{0.81} \\
\hline & $\mathrm{K}_{\mathrm{Lg}}\left(\mathrm{mg} \mathrm{DOC} \mathrm{L}^{-1} \mathrm{~d}^{-1}\right)$ & $\begin{array}{l}0.0030 \pm \\
0.014\end{array}$ & & & & \\
\hline \multirow{4}{*}{ Q-S-R ${ }^{c}$} & $\mathrm{~S}_{0}\left(\mathrm{mg} \mathrm{DOC} \mathrm{L}^{-1}\right)$ & $\begin{array}{l}27.33 \pm \\
53.70\end{array}$ & \multirow{4}{*}{0.98} & \multirow{4}{*}{18} & \multirow{4}{*}{7} & \multirow{4}{*}{$9.10^{-3}$} \\
\hline & $\mathrm{S}_{\text {to }}\left(\mathrm{mg} \mathrm{DOC} \mathrm{L}{ }^{-1}\right)$ & $\begin{array}{c}6021 \pm \\
3446259\end{array}$ & & & & \\
\hline & $\mathrm{S}_{\mathrm{nb}}\left(\mathrm{mg}\right.$ DOC L $\left.{ }^{-1}\right)$ & $\begin{array}{l}0.428 \pm \\
2.23\end{array}$ & & & & \\
\hline & $\mu_{\max }\left(d^{-1}\right)$ & $\begin{array}{c}0.210 \pm \\
0.225\end{array}$ & & & & \\
\hline
\end{tabular}

${ }^{\mathrm{a}}$ Data presented as mean $\pm \mathrm{SD}{ }^{\mathrm{b}}$ (Simkins and Alexander, 1984);

${ }^{\mathrm{c}}$ (Quiroga et al., 1999)

Equations 1, 2 and 3 proposed by Perales et al. (9) were 
used to calculate the lag time $\left(t_{L}\right), t_{50}$ (the time, starting at $t_{L}$, needed to reach $50 \%$ removal) and half-life $\left(\mathrm{t}_{1 / 2}\right)$. Substituting the values of the parameters obtained for the first order kinetic model (Table II), the mean lag time $\left(t_{\mathrm{L}}\right), \mathrm{t}_{50}$ and half-life $\left(\mathrm{t}_{1 / 2}\right)$ estimated were $0.75,4.2$ and 4.95 days, respectively.

$$
\begin{gathered}
t_{L}=-\frac{\operatorname{Ln}(0.9)}{K_{1}} \\
t_{50}=\frac{\operatorname{Ln}(0.9 / 0.5)}{K_{1}} \\
t_{1 / 2}=t_{50}+t_{L}
\end{gathered}
$$

\section{B. Acute Toxicity on Marine Organisms}

The effects of Tergitol ${ }^{\circledR} \mathrm{NP} 9$ on the microalgae growth rate are shown in Fig. 3. Mortality of the microalgae N. gaditana, I. galbana and C. gracilis was observed at higher concentrations than $8 \mathrm{mg}$ Tergitol ${ }^{\circledR}$ NP9 $\mathrm{L}^{-1}$ after 24-h exposure. D. salina and T. chuii showed lethal effects at the first exposure stage for higher concentrations than 14 and 20 mg Tergitol ${ }^{\circledR}$ NP9 $\mathrm{L}^{-1}$, respectively. However, after 24-h exposure, an increase of the microalgae population (OD $690 \mathrm{~nm}$ ) was observed even at the highest surfactant concentrations tested.
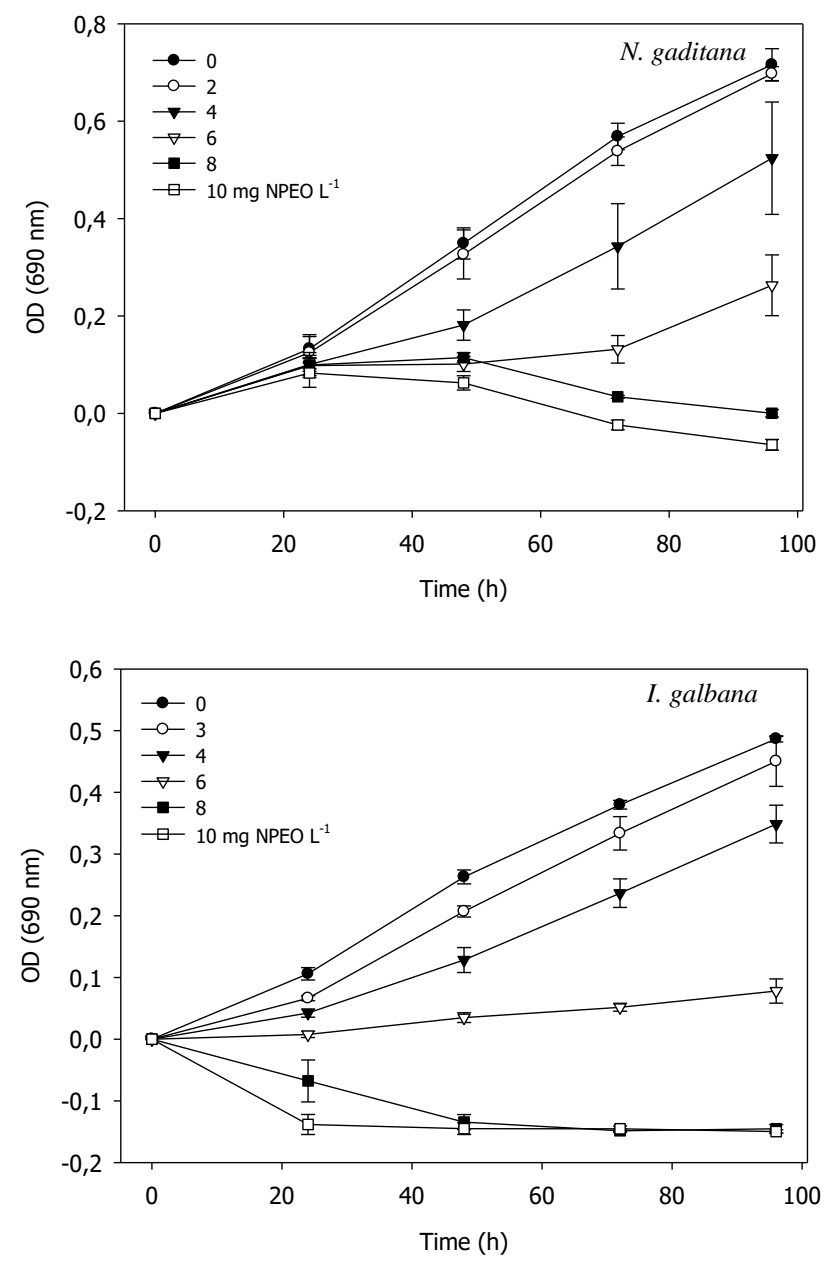
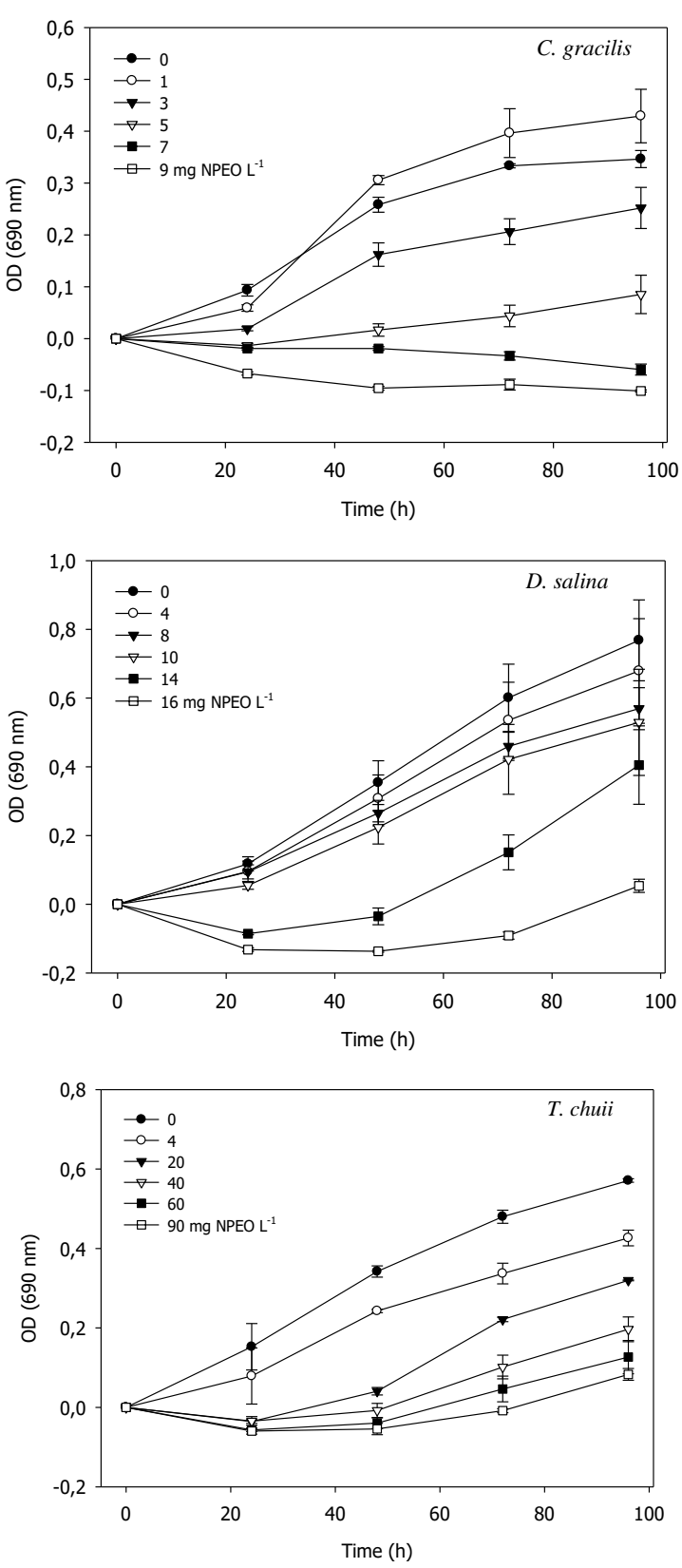

Fig. 3. Microalgae growth curves exposed to some of the Tergitol ${ }^{\circledR}$ NP9 concentrations tested. Error bars denote standard deviations between 3 replicates.

96-h $\mathrm{EC}_{50}$, NOEC and LOEC values are presented in Table III. Growth inhibition was found for I. galbana and $C$. gracilis at concentrations higher than $3 \mathrm{mg} \mathrm{L}^{-1}$ Tergitol ${ }^{\circledR} \mathrm{NP} 9$. A significant reduction in growth at surfactant concentrations equal or higher than 4 and $5 \mathrm{mg} \mathrm{L}^{-1}$ was observed for $N$. gaditana and $T$. chuii, respectively. On the contrary, high xenobiotic concentrations were required to inhibit $D$. salina growth $\left(96-\mathrm{h}\right.$ NOEC $=7.98 \mathrm{mg} \mathrm{L}^{-1}, 96-\mathrm{h}$ LOEC $=10.1 \mathrm{mg}$ $\left.\mathrm{L}^{-1}\right)$.

Dose-response curves after 48 and 72-h exposure for the nonionic surfactant Tergitol $^{\circledR}$ NP9 to A. franciscana are shown in Fig. 4. LC $_{50}$, NOEC and LOEC values after 48 and $72 \mathrm{~h}$ exposure to the surfactant are presented in Table III. No acute mortality effects were found at surfactant concentrations lower than $15.18 \mathrm{mg} \mathrm{L}^{-1}$ after 48 and $72-\mathrm{h}$ exposure (Fig. 4, Table III). A total mortality of crustacea population was not observed even at the highest concentration tested (Fig. 4). Maximum mortality 
percentages of $78 \%$ and $92 \%$ were found for a concentration of $106 \mathrm{mg}$ Tergitol ${ }^{\circledR} \mathrm{NP9} \mathrm{L}^{-1}$ after 48 and 72h, respectively.

TABLE III: ACUTE TOXICITY DATA OF TERGITOL ${ }^{\circledR}$ NP9 ON MARINE MiCROALGAE AND CRUSTACEAN

\begin{tabular}{|c|c|c|}
\hline Test organism & Endpoiont & $\begin{array}{l}\text { Concentration } \\
\left(\mathrm{mg} \mathrm{L}^{-1}\right)^{\mathrm{a}}\end{array}$ \\
\hline \multirow[t]{3}{*}{ N. gaditana } & 96-h EC $\mathrm{EC}_{50}$ & $5,41(4,99-5,73)$ \\
\hline & 96-h NOEC & 2,92 \\
\hline & 96-h LOEC & 3,99 \\
\hline \multirow[t]{3}{*}{ I. galbana } & 96-h EC $\mathrm{EC}_{50}$ & $4,57(4,32-4,84)$ \\
\hline & 96-h NOEC & 2,12 \\
\hline & 96-h LOEC & 2,92 \\
\hline \multirow[t]{3}{*}{ C. gracilis } & 96-h EC $\mathrm{EC}_{50}$ & $3,45(2,79-4,87)$ \\
\hline & 96-h NOEC & 2,12 \\
\hline & 96-h LOEC & 2,92 \\
\hline \multirow[t]{3}{*}{ D. salina } & 96-h EC $\mathrm{EC}_{50}$ & $\begin{array}{l}13,95 \\
(11,25-15,06) \\
\end{array}$ \\
\hline & 96-h NOEC & 7,98 \\
\hline & 96-h LOEC & 10,1 \\
\hline \multirow[t]{3}{*}{ T. chuii } & 96-h EC $\mathrm{EC}_{50}$ & $\begin{array}{l}25,82 \\
(22,76-29,84)\end{array}$ \\
\hline & 96-h NOEC & $<4,72$ \\
\hline & 96-h LOEC & 4,72 \\
\hline \multirow[t]{6}{*}{ A. franciscana } & $48-\mathrm{h} \mathrm{LC}_{50}$ & $41,2(34,43-47,99)$ \\
\hline & 78-h LC $\mathrm{LC}_{50}$ & $\begin{array}{l}30,34 \\
(26,06-33,84)\end{array}$ \\
\hline & 48-h NOEC & 15,18 \\
\hline & 48-h LOEC & 30,36 \\
\hline & 72-hNOEC & 15,18 \\
\hline & 72-h LOEC & 30,36 \\
\hline
\end{tabular}

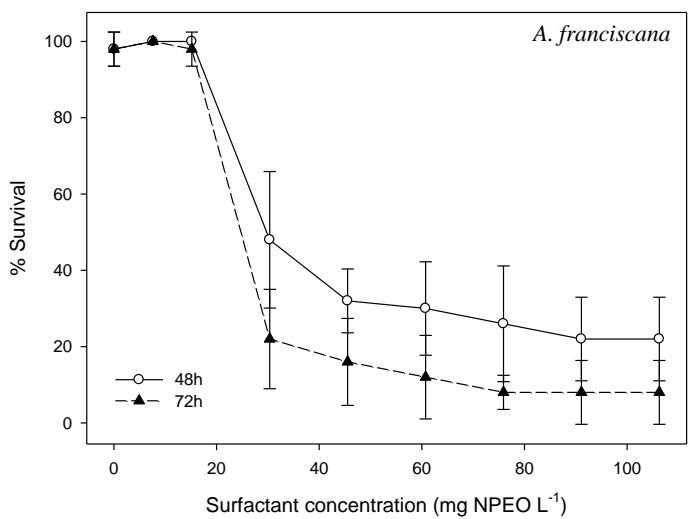

Fig. 4. Effect of Tergitol ${ }^{\circledR} \mathrm{NP} 9$ on the marine crustacean $A$. franciscana after 48-h and 72-h exposures. Data are presented as mean $\pm \operatorname{SD}(n=5)$.

\section{DISCUSSION}

Experimental results obtained in the biodegradation tests indicate a high removal rate of Tergitol $^{\circledR}$ NP9 in littoral waters under the conditions tested. The surfactant was mineralised in excess of $95 \%$ after 25 days and therefore it can be concluded that there is a potential for its biodegradation in the marine environment. These results are in agreement with those reported by other authors in river water, sea water and soils. For example, Staples et al. [18] reported ultimate biodegradation extent and half-lives of $>95 \%$ in 25 days and 7-13.6 days, respectively, using WWTP sludge as the microbial seed, household WWT systems, and unacclimated freshwater and sea water and soil. In addition, Yoshimura [6], studying the primary degradation of NP9EO, observed half-lives of 4 days in water and $>10$ days in sediments in a river die-away test. Depending on the tested temperature, primary biodegradation and mineralisation rates ranging from $68 \%$ to $96 \%$ and $30 \%$ to $70 \%$, respectively, have been also described for nonylphenol ethoxylates (NP15EO) in river water [19]. Furthermore, a relatively fast primary degradation of nonylphenol ethoxylates ( $>99 \%$ degradation after 4 days) was observed in a laboratory-scale bioreactor filled with river water.

No acclimation of the microorganisms responsible of the surfactant degradative process was necessary. However, it usually occurs when the initial cell density is much greater than the number of new organisms which could be produced from the substrate present initially [16]. Thus, studies on biodegradation of the anionic surfactant linear alkylbenzene sulphonate (LAS) in littoral waters from the same area than the present study (pristine waters) described higher lag times, ranging from 6.06 to 7.27 days [9]. These differences can be attributed to the characteristics of the enzymes responsible of the surfactant degradation. The mechanism of breakdown of LAS starts with $\omega$ and $\beta$-oxidation reactions catalysed by oxidative enzymes as for example alkane monooxygenase and dehydrogenase. In contrast, the initial stage of the degradative process of NPEOs is carried out by hydrolytic enzymes (hydrolytic reactions), which either are already presented in the natural water or synthesized relatively more quickly than the relevant oxidative enzymes [3].

First order model was found the best fitting model that describes the kinetic of the biodegradation process of the nonionic surfactant in littoral waters. This biodegradation model was proposed by Simkins and Alexander [16] and it is derived from the Monod kinetic equation. First order kinetic model including lag phase (pseudo-first order model) has been also applied for the study of the ultimate biodegradation process of commercial products alkylphenol ethoxylates and their biodegradation intermediates.

Toxic effects of Tergitol ${ }^{\circledR}$ NP9 were found to all the organisms tested. However, depending on the species tested, different surfactant tolerances were observed. Thus, marine crustacean A. franciscana presented a higher resistance than microalgae tested (Table III). Moreover, results showed $I$. galbana and $C$. gracilis were the most sensitive to the surfactant. According to the $\mathrm{EC}_{50}$ values obtained, surfactant tolerance of the microalgae tested can be summarized $T$. chuii $>$ D. salina $>N$. gaditana $>$ I. galbana $\approx C$. gracilis, with the green microalga $T$. chuii the most tolerant to the nonionic surfactant.

Toxicity data of nonylphenol ethoxylates in freshwater organisms have been widely reported in the literature [20]. However, available information concerning toxic effects of these surfactants in marine organisms is very limited. $\mathrm{EC}_{50}$ values of nonylphenol ethoxylate (Tergitol ${ }^{\circledR}$ NP9) to algae determined in the present study are in the range of corresponding values that have been reported in the literature for other species. For example, Naylor [21] found 96-h NP9EO $\mathrm{EC}_{50}$ value of $12 \mathrm{mg} \mathrm{L}^{-1}$ to the freshwater alga Selenastrum capricornutum. This values is lower than those determined in the present study for the microalgae $D$. salina and $T$. chuii, suggesting that $\mathrm{S}$. Capricornutum shows a high sensitivity to the surfactant than both microalgae. Similar results [22] were found by other authors where $T$. chuii showed a higher resistance to the ntibacterial oxytatracycline 
(OTC) than $S$. capricornutum.

$\mathrm{LC}_{50}$ value for NP9EO to A. franciscana was much higher than those registered in the literature for this surfactant in other marine and freshwater crustacea. Hall et al. (1989) reported 48-h NP9EO $\mathrm{LC}_{50}$ values of $0.92-2$ and $1.23 \mathrm{mg} \mathrm{L}^{-1}$ to the marine crustacea Mysidopsis bahia, respectively. In addition, 48-h NP9EO $\mathrm{LC}_{50}$ values of 14 and $2.9 \mathrm{mg} \mathrm{L}^{-1}$ were found for the freshwater crustacea Daphnia magna and $D$. pulex, respectively. These differences toxicities on marine and freshwater crustacean have been also reported by other authors, suggesting that $D$. magna is more sensitive to several chemicals than the Artemia sp. [23].

\section{CONCLUSIONS}

Experimental results obtained in biodegradation tests of the nonylphenol ethoxylate surfactant Tergitol ${ }^{\circledR}$ NP9 indicate that there is a potential for its biodegradation in littoral waters.

Ultimate biodegradation of Tergitol ${ }^{\circledR}$ NP9 in sea water is best described by first order kinetic model, a derived model from the growth-related Monod kinetic.

Toxicity of the nonionic surfactant depends significantly on the organism tested, being the crustacean Artemia sp. more resistant than microalgae.

Microalgae showed different sensitivity to the chemical, being $T$. chuii the most tolerant to the surfactant whereas $C$. gracilis and I. galbana were the most affected. According to the $\mathrm{EC}_{50}$ values obtained, surfactant tolerance can be summarized $T$. chuii $>D$. salina $>N$. gaditana $>$ I. galbana $\approx$ C. gracilis, ranging the $96-\mathrm{h} \mathrm{EC}_{50}$ values from 3.45 to 25.82 mg Tergitol ${ }^{\circledR} \mathrm{NP9} \mathrm{L}^{-1}$.

Based on $\mathrm{LC}_{50}$ values for freshwater and marine microalgae, it can not be concluded that marine microalgae are generally more or less sensitive to nonylphenol ethoxylates than freshwater microalgae, depending clearly on the specie tested.

Marine crustacean Artemia sp. was considerably more resistant to nonylphenol ethoxylates than other marine and freshwater crustacea.

\section{REFERENCES}

[1] D. T. Bennie, "Review of the environmental ocurrence of alkylphenols and alkylphenol ethoxylates," Water Qual Res J Canada, vol. 34, pp. 79-122, 1999.

[2] R. D. Swisher, The Analytical Methods in Surfactants Biodegradation, 2nd Edition, New York, p. 47, 1987.

[3] M. A. Manzano et al., "Effect of concentration on the biodegradation of a nonylphenol polyethoxylate in river water," Bull Environ Contam Toxicol, vol. 61, pp. 489-496, 1998.

[4] R. Renner, "European bans on surfactants trigger transatlantic debate," Environmental Science and Technology, vol. 31, pp. 316-320, 1997.

[5] H. Nyberg, "Growth of Selenastrum capricornutum in the presence of synthetic surfactants," Water Res., vol. 22, pp. 217-223, 1988.

[6] K. Yoshimura, "Biodegradation and fish toxicity of non-ionic surfactants," J. Am. Oil. Chem. Soc., vol. 63, pp. 1590-1596, 1986.

[7] R. White et al., "Environmentally persistent alkylphnolic compounds are estrogenic," Endocrinology, vol. 135, pp. 175-182, 1994.

[8] R. Vazquez-Duhalt et al., "Nonylphenol, an integrated vision of a pollutant," Appl. Ecol. Environ. Res., vol. 4, pp. 1-25, 2006.

[9] J. A. Perales et al., "Biodegradation kinetics of linear alkylbenzene sulphonates in sea water," Biodegradation, vol. 18, pp. 63-70, 2007.

[10] APHA, AWWA, WPCF, Standard Methods for the Examination of Water and Wastewater, 18th ed., Washington, DC., 1992.
[11] USEPA, Methods for Measuring the Acute Toxicity of Effluents and Receiving Waters to Freshwater and Marine Organisms, EPA-821-R-02-012 5th ed., USEPA, Washington, DC, 2002.

[12] OECD, "Series on testing and assessment. Number 10-Report of the OECD workshop on statistical analysis of aquatic toxicity data," ENV/MC/CHEM(98)18, OECD, Paris, 1998.

[13] ASTM, "Standard guide for conducting static and flow-through acute toxicity tests with mysids from the west coast of the United States," Annual Book of ASTM Standards, vol. 11.06, ASTM, Philadelphia, PA, 2004.

[14] W. A. Press et al., Numerical Recipes, the Art of Scientific Computing, Cambridge University Press, Cambridge, 1986.

[15] T. J. Norberg-King, "An interpolation estimate for chronic toxicity: The ICp approach,” NETAC Technical Report o5-88, ESEPA, Duluth, MN, 1988.

[16] S. Simkins and M. Alexander, "Models for mineralization kinetics with the variables of substrate concentration and population density," Appl Environ Microbiol, vol. 47, pp. 1299-1306, 1984.

[17] J. M. Quiroga et al., "Biodegradation kinetics of surfactants in seawater," Chemosphere, vol. 39, pp. 1957-1969, 1999.

[18] C. A. Staples et al., "Ultimate biodegradation of alkylphnol ethoxilate surfactants and their biodegradation intermediates," Environ. Toxicol. Chem., vol. 20, pp. 2450-2455, 2001.

[19] M. A. Manzano et al., "The effect of temperature on the biodegradation of a nonylphenol polyethoxylate in river water," Water Res., vol. 33, pp. 2593-2600, 1999.

[20] M. Isidori et al., "Toxicity on crustaceans and endocrine disrupting activity on Saccharomyces cerevisiae of eight alkylphenols," Chemosphere, vol. 64, pp. 135-143, 2006.

[21] C. G. Naylor, "Environmental fate and safety of nonylphenol ethoxylates," American Association of Textile Chemists and Colourists, vol. 27, pp. 29-33, 1995.

[22] C. S. Ferreira, et al., "Acute toxicity of oxytetracycline and florfenicol to the microalgae Tetraselmis chuii and to the crustacean Artemia parthenogenetica," Ecotoxicol. Environ. Saf., vol. 67, pp. 452-458, 2007.

[23] R. Guerra, "Ecotoxicological and chemical evaluation of phenolic compounds in industrial effluents," Chemosphere, vol. 44, pp. 1737-1747, 2001.

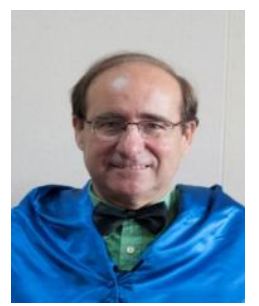

José María Quiroga Alonso was born in Cáceres (Spain) in 1955. He graduate chemical sciencies (1978) and Ph.D. in chemical science (1985) in the Cádiz University (Spain).

José María has been director of the Department Chemical Engineering (2004-2008), director of the Department Environmental Technology (2008-2012) and dean of Faculty of Marine and Environmenta Science (2012-2016)

José María Quiroga is full professor of environmental technology in Dept. Envoronmental Technology in Cádiz University courses for graduated students and $\mathrm{Ph} . \mathrm{D}$. students in environmental engineering and environmental contamination. He has directed $20 \mathrm{Ph}$.D. thesis in subjects related to engineering and environmental pollution.

Dr. Quiroga he has conducted the following research activities: Principal investigator/partner of several international and national research projects $\mathrm{He}$ is author/coauthor of 200 papers published in international and national peer reviewed journals and 149 communications in international congresses and 56 national congresses. He is coauthor of one book and co-author off 43 chapters of different books.

The main topics of interest in his research are: Biodegradation of xenobiotic compounds, Desalination and Water Reuse (membranes treatment), Biological Treatment, Application of Advanced Oxidation Process (AOP) of water treatment (drinking water and wastewater) and Water treatment for small communities.

He has frequently acted as reviewer for impact factor journals. In addition, he is an evaluator of research projects for different national and international agencies and he has been a member of the National Project Evaluation Commission of the Spanish Plan for Research, Development and Innovation.

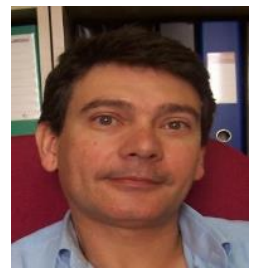

Luis I. Romero-García was born in Cádiz on December $18^{\text {th }}, 1960$ and he was graduated in chemical sciences in 1982, obtaining a $\mathrm{PhD}$ in chemical sciences in 1991 at the University of Cádiz (Spain).

In January 1984, he earned a research fellowship, financed by the Spanish Ministry of Education, to conduct his doctoral studies. Later, in 1988, he 
reached a position as high school professor of Physics and Chemistry. In 1993, he got a position as Professor of Chemical Engineering at the University of Cádiz. Finally, since 2010, he holds a position of Full Professor of Chemical Engineering at the Department of Chemical Engineering and Food Technology of the University of Cádiz (Spain). He is co-author of more than 100 papers, most of them published in high impact factor journals (http://orcid.org/0000-0001-5193-7600). In addition, he is co-author of 28 books or book chapters, more than 150 communications in congresses and 7 international patents. The main topics of interest in his research career have been related to energy production (bio-hydrogen and bio-methane) from wastes by anaerobic processes. Currently, he is engaged in the study of polyhydroxialcanoates (PHAs) production from volatile fatty acids (VFAs) generated by dark fermentation.

Prof. Romero-García has been involved in more than 50 Research Projects, being responsible for 14 of them. He has frequently acted as reviewer for more than 17 high impact factor journals. In addition, he is a regular evaluator of research projects for different national and international agencies and he has been a member of the National Project Evaluation Commission of the Spanish Plan for Research, Development and Innovation.

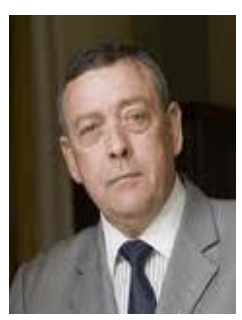

Diego Sales-Marquez received the $\mathrm{PhD}$ by University of Seville (1980). He is full professor of the University of Cadiz (Spain) on Chemical Engineering (1990) and later full professor on environmental technologies (1993). The experience of Prof. Sales in academic management and R \& D \& i project management is huge: more than 25 years between vice-rector of students and planning (1985-1995), dean of the Faculty of Marine and
Environmental Sciences (1996 -2003) and rector of the University of Cadiz, UCA (Spain) between May 2003 and July 2011. He has also been president of teaching assessment committees in Spanish universities and he is currently the Head of the Department of Environmental Technologies of the University of Cádiz. He was Vice-President of the Council of Universities of Spain for seven years between 2005 and July 2011, when he resigned as Rector of the University of Cádiz, Vice-President of the Association of Public Universities of Andalusia (2009-2011) and Vice-President of the University Association Ibero-American postgraduate, AUIP (2009 until his resignation as Rector).Since 1989, he has been responsible of the research group TEP 181 "Technology for the Environment" (http://tmagroup.es) of the Andalusian Plan for Research, Technological Development and Innovation of Andalusia (PAIDI). The global activity of this research group has been recognized as "excellent" by the Andalusian Agency of Knowledge. Prof. Sales has thirty six years of scientific productivity recognized by the National Evaluation Commission of Research Activity (Spain). He has participated in more than 60 national and international $\mathrm{R}+\mathrm{D}+\mathrm{i}$ projects (most of them as the main researcher). He has supervised more than twenty doctoral theses, has published more than 240 articles in specialized journals with high impact index, has presented more than 350 papers / plenary lectures / communications in the best international and national congresses of its specialty, mainly environmental engineering, and he has 6 registered patents. Also, he is Doctor Honoris Causa by several universities, emphasizing the Federico Villarreal National University (Lima, Peru. 2010) and the National University of San Agustín de Arequipa (Arequipa, Peru, July 2012). 